\title{
Qualidade de vida em indivíduos com gagueira desenvolvimental persistente ${ }^{* * * * * *}$
}

\section{Quality of life of individuals with persistent developmental stuttering}

\author{
Claudia Regina Furquim de Andrade* \\ Fernanda Chiarion Sassi** \\ Fabiola Staróbole Juste*** \\ Beatriz Ercolin****
}

*Fonoaudióloga. Professora Titular do Departamento de Fisioterapia,

Fonoaudiologia e Terapia Ocupacional da Faculdade de Medicina da

Universidade de São Paulo. Endereço para correspondência:

Rua Cipotanea, 51 - São Paulo - SP -

CEP 05360-160

(revista@profono.com.br).

**Fonoaudióloga. Doutora em Ciências pela Faculdade de Medicina da Universidade de São Paulo. Fonoaudióloga do Departamento de Fisioterapia, Fonoaudiologia e Terapia Ocupacional da Faculdade de Medicina da Universidade de São Paulo.

***Fonoaudióloga. Pós-Doutoranda em Ciências pela Faculdade de Medicina da Universidade de São Paulo.

****Fonoaudióloga. Especialização em Motricidade e Funções Orofaciais pelo Curso de Fonoaudiologia da Faculdade de Medicina da Universidade de São Paulo. Fonoaudióloga da Prefeitura de São Bernardo do Campo - São Paulo.

*****Trabalho Realizado no Departamento de Fonoaudiologia, Fisioterapia e Terapia Ocupacional da Faculdade de Medicina da Universidade de São Paulo.

Artigo Original de Pesquisa

Artigo Submetido a Avaliação por Pares

Conflito de Interesse: não

\section{Abstract}

Background: quality of life. Aim: to verify the influence of the readiness of speech - regarding affective, behavioral and cognitive reactions - over the life quality of fluent individuals and those with persistent developmental stuttering (PDS). Method: 40 adults divided in two groups, paired by gender and age. The research group (GI) consisted of 20 individuals with PDS, with no other associated deficit. The research group (GII) consisted of 20 fluent individuals. All of the participants answered a Self-Assessment Protocol - version for adults. This protocol is composed by three thematic sessions, each one presenting five questions. Each question should be answered by choosing a number on a scale that varies from 1 (completely disagree) to 7 (completely agree). The first session corresponds to the affective reactions, the second to the behavioral reactions and the third to the cognitive reactions. All of the participants answered all of the 15 questions. Results: the findings indicate that a difference in the perception of speech and speech fluency exists between fluent individuals and individuals with PDS. For the individuals with PDS, the different stuttering severity levels did not present divergent points; on the contrary, even the individuals with mild PDS presented the same affective, behavioral and cognitive profiles of those with a more severe stuttering. Conclusion: the results indicate that the experience with stuttering is different among the individuals in terms of the observable speech characteristics, functional communication difficulties experienced by the individual in everyday situations, having a negative impact in the quality of life.

Key Words: Quality of Life; Stuttering; Methods.

\section{Resumo}

Tema: qualidade de vida. Objetivo: conhecer a influência da habilidade de fala - quanto as reações afetivas, comportamentais e cognitivas - sobre a qualidade de vida de indivíduos fluentes e com gagueira persistente do desenvolvimento (GPD). Método: 40 indivíduos adultos divididos em dois grupos, pareados por gênero e idade. O grupo de pesquisa (GI) foi composto por 20 indivíduos com PDS, sem qualquer outro déficit associado. O grupo controle (GII) foi composto por 20 indivíduos fluentes. Todos os participantes responderam ao Protocolo de Auto-Avaliação - versão para adultos. O protocolo é composto por três sessões de temáticas, cada uma delas com cinco questões, sendo que cada pergunta pode ser respondida numa escala de 1 (discordo plenamente) a 7 (concordo plenamente). A primeira sessão corresponde aos componentes afetivos, a segunda aos componentes comportamentais e a terceira aos componentes cognitivos. Todos os participantes responderam a todas as 15 questões. Resultados: os achados indicaram que existe diferença na percepção da fala e da fluência entre indivíduos fluentes e com PDS. No grupo de indivíduos com PDS os diferentes graus de gravidade da patologia não identificaram pontos de divergência, ao contrário, mesmo os indivíduos com PDS leve apresentaram o mesmo perfil afetivo, comportamental e cognitivo que os indivíduos com maior comprometimento da fluência da fala. Conclusão: pelos resultados do estudo foi observado que a experiência com a gagueira diferencia os indivíduos em termos das características observáveis de fala, das dificuldades funcionais de comunicação vivida pelo falante no seu dia a dia gerando impacto negativo na qualidade de vida do indivíduo.

Palavras-Chave: Qualidade de Vida; Gagueira; Métodos. 


\section{Introduction}

In the last two decades there has been a growing discussion about the importance of evidence-based practice in the field of the SpeechLanguage and Hearing Sciences. The need for clinicians to document the results of their intervention has been particularly apparent in the field of fluency disorders (1-7).

One of the central tenets of an evidence-based approach is the measurement and evaluation of treatment outcomes. In fluency disorders numerous studies have documented the effects of existing treatments on factors such as clinician-rated frequency of speech disruptions, speech naturalness, and speaking rate (8-10). Results from these studies have clearly demonstrated that treatment can effectively minimize these observable symptoms of the disorder.

However, a few authors have been discussing a few aspects of stuttering other than those that can be objectively measured (6-7,11-14). These authors point that stuttering can affect an individual's life, in the sense that this individual can, over time, develop feelings of shame and guilt associated to his/hers speech performance. In this sense, researches that investigate the selfassessment and self-perception of individuals with stuttering are of great importance.

Several studies have focused primarily on the impact stuttering has over the quality of life of those who stutter, focusing on the social and professional negative experiences, as well as on the negative emotions associated to the ability to speak and communicate (6-8).

Quality of life is the perception of individuals of their positions in life in the culture and value system in which they live, relative to their goals, expectations, standards and concerns (15-21).

To describe stuttering based on the point of view of those who stutterer, broadens the knowledge about the possible negative effects that the involuntary speech disruptions have over the life of these individuals.

The purpose of this research is to investigate the influence of the ability to speak - regarding affective, behavioral and cognitive reactions - over the quality of life of fluent individuals and those with persistent developmental stuttering.

\section{Method}

The selection and assessment procedures of the participants only began after the pertinent ethical procedures: approval by the Ethics Committee (CAPPesq HCFMUSP0823/07) and informed signed consent of all of the participants. The research did not involve any invasive or experimental technique, characterizing the research as a no risk study.

\section{Participants}

Participants of this study were 40 adults (ages above 18 years; mean age of 34.5 years), of both genders ( 20 females and 20 males), divided in two groups paired by age and gender.

The research group (GI) consisted of 20 individuals with persistent developmental stuttering (PDS), with no other associated communicative, neurologic or cognitive deficit. Stuttering was diagnosed according to the following criteria:

. fluency profile scores outside the reference values for age (22);

.11 points or more (a stuttering severity of at least "mild") on the Stuttering Severity Instrument - 3 (SSI-3) (23). Participants of this group were subdivided according to their severity of stuttering: 5 mild; 5 moderate; 5 severe and 5 very severe.

The control group (GII) consisted of 20 fluent individuals, with no stuttering complaints and with no communicative, neurologic and cognitive deficits. The inclusion criteria of the participants of GII were:

. fluency profile scores within the reference values for age (22);

. 10 points (severity equivalent to "very mild") or less in the SSI-3 (23);

. no family history of recuperated or persistent stuttering.

Procedures

In order to obtain the research data, the participants individually filled in a Self-Assessment Protocol (which can also be used to assess the functional results of stuttering treatment) - Version for Adults (24).

This protocol is composed by 3 thematic sessions, each one containing 5 questions that should be answered according to a scale that ranges from 1 (completely disagree) to 7 (completely agree). The first session is related to the affective reactions, the second session is related to the behavioral 
reactions and the third is related to the cognitive reactions. All of the participants answered all of the 15 questions.

\section{Results}

The obtained data were statistically treated using the Test of Equal Proportions. This is a nonparametric test and compares the proportion of answers of two determined variables and/or their levels, indicating their statistical significance. The adopted level of significance was of $\mathrm{p}=0.05$, with all intervals at $95 \%$ of statistical confidence. Although the classification of the answers varied in seven points, it was decided for this analysis that the intermediate values corresponded to very close concepts and for this reason the 3 points that corresponded to answers of disagreement were grouped together. The neutral point was maintained and the other 3 points that corresponded to answers of agreement were also grouped together. Thus, for statistical purposes, each question had 3 possible answers (1/disagree; $2 /$ neutral; 3/agree).

In the inter-group comparison, the results consistently indicate that a significant statistical difference exists between the groups for the answers 1 and 3, were Answers 1 (disagree) occur more frequently $(<0.001$ to 0.037$)$ in GI and Answers 3 (agree) occur more frequently $(<0.001$ to 0.037$)$ in group GII. These differences are consistent for all of the reactions: affective, behavioral and cognitive (except for the cognitive reaction in question $\mathrm{E}$, related to the need for therapy). It is important to highlight that the individuals with PDS have doubts about the effectiveness of treatment for stuttering.

The comparison between the different stuttering severity levels of the individuals with PDS is described in the tables below:

The statistically significant results were:
Affective Reactions (Table 1):

. question A: difference between moderate and very severe (0.003) - like less to communicate;

. question B: difference for all, worse for the mild (0.003 to <0.001) - all feel discomfort to communicate;

. question C: difference for mild and moderate $(0.012$ to $<0.001$ ) - don't like the sound of their own voice; . question D: difference for all, worse for the mild (0.041 to <0.001) - do not control speech in difficult situations;

. question E: difference for all $(<0.001)$ - are not satisfied with their own fluency.

Behavioral Reactions (Table 2):

question A: difference for all with the expection of the mild (0.012) - avoid communication situations; . question B: difference for all $(<0.001)$ - all avoid words;

. question $\mathrm{C}$ : difference for all, worse for the very severe $(0.003$ to $<0.001)$ - to not observe fluency in their speech;

. question D: difference for all (0.031 to 0.003) - use strategies to improve speech fluency;

. question E: difference for all $(0.031$ to $<0.001)$ observe physical concomitants.

Cognitive Reactions (Table 3):

. question A: difference for all $(<0.001)$ - agree that they need therapy;

. question B: difference for all $(<0.001)$ - agree that their speech affects negatively their professional success;

. question C: difference for all $(<0.001)$ - agree that their speech affects negatively their social success; . question D: difference for all $(<0.001)$ - do not understand their speech problem;

.question E:not significant for all - do not believe in the success of therapy. 
TABLE 1 . Affective reactions and stuttering severity.

\begin{tabular}{|c|c|c|c|c|c|}
\hline \multicolumn{3}{|c|}{ Affective reactions } & Mild & Moderate & Severe \\
\hline \multirow{15}{*}{ Answer 1} & \multirow{3}{*}{ A } & Moderate & 0.114 & & \\
\hline & & Severe & $-\mathrm{x}-$ & 0.114 & \\
\hline & & Very Severe & 0.114 & 1.000 & 0.114 \\
\hline & \multirow{3}{*}{ B } & Moderate & 0.490 & & \\
\hline & & Severe & 0.197 & 0.527 & \\
\hline & & Very Severe & 0.490 & 1.000 & 0.527 \\
\hline & \multirow{3}{*}{$\mathrm{C}$} & Moderate & 0.114 & & \\
\hline & & Severe & 0.038* & $0.002 *$ & \\
\hline & & Very Severe & 0.527 & 0.038* & 0.114 \\
\hline & \multirow{3}{*}{$\mathrm{D}$} & Moderate & 0.197 & & \\
\hline & & Severe & 0.197 & 1.000 & \\
\hline & & Very Severe & 0.197 & 1.000 & 1.000 \\
\hline & \multirow{6}{*}{ A } & Moderate & 0.292 & & \\
\hline & & Severe & 1.000 & 0.292 & \\
\hline & & Very Severe & 1.000 & 0.292 & 1.000 \\
\hline \multirow{15}{*}{ Answer 2} & & Moderate & 1.000 & & \\
\hline & & Severe & 0.292 & 0.292 & \\
\hline & & Very Severe & 0.292 & 0.292 & $-x-$ \\
\hline & \multirow{3}{*}{ B } & Moderate & $-\mathrm{x}-$ & & \\
\hline & & Severe & 0.292 & 0.292 & \\
\hline & & Very Severe & $-x-$ & $-\mathrm{x}-$ & 0.292 \\
\hline & \multirow{3}{*}{$\mathrm{C}$} & Moderate & $-x-$ & & \\
\hline & & Severe & $-\mathrm{x}-$ & $-\mathrm{x}-$ & \\
\hline & & Very Severe & 0.292 & 0.292 & 0.292 \\
\hline & \multirow{3}{*}{$\mathrm{D}$} & Moderate & $-\mathrm{x}-$ & & \\
\hline & & Severe & $-\mathrm{X}-$ & $-\mathrm{x}-$ & \\
\hline & & Very Severe & $-\mathrm{x}-$ & $-x-$ & $-\mathrm{x}-$ \\
\hline & \multirow{3}{*}{$\mathrm{E}$} & Moderate & $-\mathrm{x}-$ & & \\
\hline & & Severe & $-x-$ & $-x-$ & \\
\hline & & Very Severe & $-\mathrm{x}-$ & $-x-$ & $-x-$ \\
\hline \multirow{15}{*}{ Answer 3} & \multirow{3}{*}{ A } & Moderate & 0.197 & & \\
\hline & & Severe & 0.292 & 0.038* & \\
\hline & & Very Severe & 0.490 & 0.527 & 0.114 \\
\hline & \multirow{3}{*}{ B } & Moderate & 0.490 & & \\
\hline & & Severe & 0.490 & 1.000 & \\
\hline & & Very Severe & 0.490 & 1.000 & 1.000 \\
\hline & \multirow{3}{*}{$\mathrm{C}$} & Moderate & 0.114 & & \\
\hline & & Severe & 0.038* & $0.002 *$ & \\
\hline & & Very Severe & 1.000 & 0.114 & 0.038* \\
\hline & \multirow{3}{*}{ D } & Moderate & 0.197 & & \\
\hline & & Severe & 0.197 & 1.000 & \\
\hline & & Very Severe & 0.197 & 1.000 & 1.000 \\
\hline & \multirow{3}{*}{$\mathrm{E}$} & Moderate & 0.292 & & \\
\hline & & Severe & 1.000 & 0.292 & \\
\hline & & Very Severe & 1.000 & 0.292 & 1.000 \\
\hline
\end{tabular}


TABLE 2. Behavioral reactions and stuttering severity.

\begin{tabular}{|c|c|c|c|c|c|}
\hline \multicolumn{3}{|c|}{ Behavioral reactions } & Mild & Moderate & Severe \\
\hline \multirow{15}{*}{ Answer 1} & \multirow{3}{*}{ A } & Moderate & 0.197 & & \\
\hline & & Severe & 0.197 & 1.000 & \\
\hline & & Very Severe & 0.527 & 0.490 & 0.490 \\
\hline & \multirow{3}{*}{ B } & Moderate & 0.490 & & \\
\hline & & Severe & 0.058 & 0.197 & \\
\hline & & Very Severe & 1.000 & 0.490 & 0.058 \\
\hline & \multirow{3}{*}{$\mathrm{C}$} & Moderate & 1.000 & & \\
\hline & & Severe & 0.114 & 0.114 & \\
\hline & & Very Severe & 0.527 & 0.527 & 0.038* \\
\hline & \multirow{3}{*}{$\mathrm{D}$} & Moderate & 0.527 & & \\
\hline & & Severe & 0.527 & 1.000 & \\
\hline & & Very Severe & 0.527 & 1.000 & 1.000 \\
\hline & \multirow{3}{*}{$\mathrm{E}$} & Moderate & 0.038 & & \\
\hline & & Severe & 0.038 & 1.000 & \\
\hline & & Very Severe & 0.292 & 0.197 & 0.197 \\
\hline \multirow{15}{*}{ Answer 2} & \multirow{3}{*}{ A } & Moderate & 1.000 & & \\
\hline & & Severe & 1.000 & 1.000 & \\
\hline & & Very Severe & 0.292 & 0.292 & 0.292 \\
\hline & \multirow{3}{*}{$\mathrm{B}$} & Moderate & 0.292 & & \\
\hline & & Severe & 1.000 & 0.292 & \\
\hline & & Very Severe & 0.292 & $-x-$ & 0.292 \\
\hline & \multirow{3}{*}{$\mathrm{C}$} & Moderate & 0.114 & & \\
\hline & & Severe & 0.114 & $-x-$ & \\
\hline & & Very Severe & 0.114 & $-x-$ & $-\mathrm{x}-$ \\
\hline & \multirow{3}{*}{$\mathrm{D}$} & Moderate & $-\mathrm{x}-$ & & \\
\hline & & Severe & $-\mathrm{x}-$ & $-x-$ & \\
\hline & & Very Severe & $-\mathrm{x}-$ & $-x-$ & $-x-$ \\
\hline & \multirow{3}{*}{$\mathrm{E}$} & Moderate & $-\mathrm{x}-$ & & \\
\hline & & Severe & $-\mathrm{x}-$ & $-x-$ & \\
\hline & & Very Severe & $-\mathrm{x}-$ & $-x-$ & $-x-$ \\
\hline \multirow{15}{*}{ Answer 3} & \multirow{3}{*}{ A } & Moderate & 0.197 & & \\
\hline & & Severe & 0.197 & 1.000 & \\
\hline & & Very Severe & 0.197 & 1.000 & 1.000 \\
\hline & \multirow{3}{*}{ B } & Moderate & 0.114 & & \\
\hline & & Severe & 0.038* & 0.527 & \\
\hline & & Very Severe & 0.292 & 0.490 & 0.197 \\
\hline & \multirow{3}{*}{$\mathrm{C}$} & Moderate & 0.197 & & \\
\hline & & Severe & $0.010 *$ & 0.114 & \\
\hline & & Very Severe & 0.490 & 0.527 & 0.038* \\
\hline & \multirow{3}{*}{$\mathrm{D}$} & Moderate & 0.527 & & \\
\hline & & Severe & 0.527 & 1.000 & \\
\hline & & Very Severe & 0.527 & 1.000 & 1.000 \\
\hline & \multirow{3}{*}{$\mathrm{E}$} & Moderate & $0.038 *$ & & \\
\hline & & Severe & 0.038* & 1.000 & \\
\hline & & Very Severe & 0.292 & 0.197 & 0.197 \\
\hline
\end{tabular}


TABLE 3. Cognitive reactions and stuttering severity

\begin{tabular}{|c|c|c|c|c|c|}
\hline \multicolumn{3}{|c|}{ Cognitive reactions } & Mild & Moderate & Severe \\
\hline \multirow{15}{*}{ Answer 1} & \multirow{3}{*}{ A } & Moderate & 0.197 & & \\
\hline & & Severe & 0.038* & 0.292 & \\
\hline & & Very Severe & 0.038* & 0.292 & $-x-$ \\
\hline & \multirow{3}{*}{ B } & Moderate & $-\mathrm{x}-$ & & \\
\hline & & Severe & 0.292 & 0.292 & \\
\hline & & Very Severe & 0.292 & 0.292 & 1.000 \\
\hline & \multirow{3}{*}{$\mathrm{C}$} & Moderate & 0.292 & & \\
\hline & & Severe & 0.292 & 1.000 & \\
\hline & & Very Severe & $-\mathrm{x}-$ & 0.292 & 0.292 \\
\hline & \multirow{3}{*}{$\mathrm{D}$} & Moderate & 1.000 & & \\
\hline & & Severe & 0.527 & 0.527 & \\
\hline & & Very Severe & 0.490 & 0.490 & 0.197 \\
\hline & \multirow{3}{*}{$\mathrm{E}$} & Moderate & 1.000 & & \\
\hline & & Severe & 0.292 & 0.292 & \\
\hline & & Very Severe & 0.292 & 0.292 & $-x-$ \\
\hline \multirow{15}{*}{ Answer 2} & \multirow{3}{*}{ A } & Moderate & 0.292 & & \\
\hline & & Severe & 0.292 & $-x-$ & \\
\hline & & Very Severe & 0.292 & $-x-$ & $-x-$ \\
\hline & \multirow{3}{*}{ B } & Moderate & $-x-$ & & \\
\hline & & Severe & $-\mathrm{x}-$ & $-x-$ & \\
\hline & & Very Severe & $-\mathrm{x}-$ & $-\mathrm{X}-$ & $-x-$ \\
\hline & \multirow{3}{*}{$\mathrm{C}$} & Moderate & 0.292 & & \\
\hline & & Severe & $-\mathrm{x}-$ & 0.292 & \\
\hline & & Very Severe & $-\mathrm{x}-$ & 0.292 & $-x-$ \\
\hline & \multirow{3}{*}{$\mathrm{D}$} & Moderate & 0.292 & & \\
\hline & & Severe & $-\mathrm{X}-$ & 0.292 & \\
\hline & & Very Severe & 0.292 & 1.000 & 0.292 \\
\hline & \multirow{3}{*}{$\mathrm{E}$} & Moderate & 0.292 & & \\
\hline & & Severe & 1.000 & 0.292 & \\
\hline & & Very Severe & 1.000 & 0.292 & 1.000 \\
\hline \multirow{15}{*}{ Answer 3} & \multirow{3}{*}{ A } & Moderate & 0.490 & & \\
\hline & & Severe & 0.114 & 0.292 & \\
\hline & & Very Severe & 0.114 & 0.292 & $-x-$ \\
\hline & \multirow{3}{*}{$\mathrm{B}$} & Moderate & $-\mathrm{x}-$ & & \\
\hline & & Severe & 0.292 & 0.292 & \\
\hline & & Very Severe & 0.292 & 0.292 & 1.000 \\
\hline & \multirow{3}{*}{$\mathrm{C}$} & Moderate & $-\mathrm{x}-$ & & \\
\hline & & Severe & 0.292 & 0.292 & \\
\hline & & Very Severe & $-x-$ & $-x-$ & 0.292 \\
\hline & \multirow{3}{*}{ D } & Moderate & 0.490 & & \\
\hline & & Severe & 0.527 & 0.197 & \\
\hline & & Very Severe & 0.114 & 0.292 & 0.038* \\
\hline & \multirow{3}{*}{$\mathrm{E}$} & Moderate & 0.490 & & \\
\hline & & Severe & 0.490 & 1.000 & \\
\hline & & Very Severe & 0.490 & 1.000 & 1.000 \\
\hline
\end{tabular}




\section{Discussion}

The results of the present study indicate that there is a difference in the perception of speech and speech fluency between fluent individuals and those with PDS. For the group of individuals with PDS, the different severity levels of the pathology did not identify divergent points; on the contrary, even individuals with mild PDS present affective, behavioral and cognitive reactions similar to those with a more severe stuttering problem.

As pointed in the consulted literature, although many people who stutter have written about their personal experiences of stuttering, very little systematic research appears to have been conducted regarding the perceived impact of this communication disability on quality of life (25-26).

Findings of the present study agree with those pointed in the literature, indicating that the experience of stuttering for the person who stutters may include negative affective, behavioral, and cognitive reactions and may also involve significant limitations in the individual's ability to participate in daily activities and a negative effect on the person's overall quality of life $(6-7,25)$.

A few authors believe that severe communication disabilities are likely to exert a negative impact on the quality of life as they cause frustration for those individuals who experience them. The enjoyment of many of life's activities can be severely restricted when people attend to the manner of speaking more than the message it carries, which may be the cause of stuttering (67,25 ). Consequently, communication disorders such as stuttering, are likely to exert profound influence on the person at all stages of the life cycle; for example during the school-age, studies have shown that children who stutter tend to perform below average when compared to their fluent pairs (13).

\section{Conclusion}

Through the results of the present study, it was possible to observe that the experience with stuttering differentiates individuals in terms of the observable speech characteristics and in terms of the functional communication difficulties experienced daily, thus having a negative impact on the individual's overall quality of life.

\section{References}

1. Thomas C, Howell P. Assessing efficacy of stuttering treatments. Journal of Fluency Disorders. 2001;26:31133.

2. Bothe AK. Evidence-based treatment of stuttering: V. The art of clinical practice and the future of clinical research. Journal of Fluency Disorders. 2003;28:247-58.

3. Finn P. Evidence-based treatment of stuttering: II. Clinical significance of behavioral stuttering treatments. Journal of Fluency Disorders. 2003;28:209-18.

4. Ingham JC Evidence-based treatment of stuttering: I. Definition and application. Journal of Fluency Disorders. 2003;28:197-208.

5. Onslow M. Evidence-based treatment of stuttering: IV. Empowerment through evidence-based treatment practices. Journal of Fluency Disorders. 2003;28:237-46.

6. Yaruss JS, Quesal RW. Stuttering and the International Classification of Functioning, disability, and health (ICF): an update. Journal of Communication Disorders. 2004;37:35-52.

7. Yaruss JS, Quesal RW. Overall assessment of the speaker's experience of Stuttering (OASES): documenting multiple outcomes in stuttering treatment. Journal of Fluency Disorders. 2006;31:90-115.
8. Onslow M, Costa L, Andrews, C, Harrison, E. Speech outcomes of a prolonged-speech treatment for stuttering. Journal of Speech and Hearing Research. 1996;39:734-49.

9. Schiavetti N, Metz, DE. Stuttering and the measurement of speech naturalness. In R. F. Curlee \& G. M. Siegel (Eds.), Nature and treatment of stuttering: New directions. Boston: Allyn \& Bacon; 1997. p. 398-412.

10. Andrade CRF de. Protocolo para avaliação da fluência da fala. Pró-Fono. 2000;12(2):131-4.

11. Starkweather CW. Issues in the efficacy of treatment for fluency disorders. Journal of Fluency Disorders. 1993;18:151-68.

12. St. Louis KO. Living with stuttering. Morgantown, WV: Populore Publishing Company; 2001.

13. Klompas M, Ross E. Life experiences of people who stutter, and perceived impacto f stuttering on quality of life: personal accounts of South African individuals. 2004. Journal of Fluency Disorders. 2004;29:275-305.

14. Yaruss JS. Evaluating treatment outcomes for adults who stutter. Journal of Communication Disorders. 2001;34:163-82. 
15.Carroll REO, Smith K, Couston N, Cossar JA, Hayes PC. A comparison of the WHOQOL-100 and the WHOQOL-bref in detecting change in quality of life following liver transplantation. Quality of life research. 2000;9:121-4

16. Glatzer W. Quality of life in the Europian Union and the United States of America: evidence from comprehensive indices. Applied research in quality of life. 2006;1:169-88.

17. Kober R, Eggleton IRC. Using quality of life to assess performance in the disability services sector. Applied research in quality of life. 2006;1:63-77.

18. Michalos AC, Sirg MJ, Estes RJ. Introducing the Official Journal of he International Society for quality of life studies: applied research in quality of life (ARQOL). Applied research in quality of life. 2006;1:1-3.

19. Ferris AL. Atheory of social structure and quality of life. Applied research in quality of life. 2006;1:117-23.

20. Ciconelli RM, Soarez PC, Kowalski CCG, Ferraz MB. The Brazilian Portuguese version of the work productivity and activity impairment - general health (WPAI_GH) questionnaire. São Paulo Medical Journal. 2006;124(6):32532.
21. Flect MPA, et al. Aplicação da versão em português do instrumento abreviado de avaliação da qualidade de vida WHOOQOL-bref. Journal of Public Health. 2000;34(2):178-83.

22. Andrade CRF de. Perfil da fluência da fala:parâmetros comparativos diferenciado por idade para crianças, adolescentes, adultos e idosos. Série livros digitais de pesquisa financiados por agências de fomento. Barueri: Pró-Fono; 2006.

23. Riley G.D. A Stuttering Severity Instrument for children and adults. Austin, Pro-Ed; 1994. p. 21.

24. Campanatti-Ostiz H, Andrade CRF de. Gagueira: Manutenção, generalização e transferência. Pró-Fono. 2000;12(2):121-30

25. O'Keefe, B. M. Communication disorders. In R. Renwick, Brown I, Nagler M. (eds.), Quality of life in health promotion and rehabilitation. London: Sage Publications; 2006. p. 219-36.

26. Blood GW, Blood, IM, Tellis, G, Gabel, R. Communication apprehension and self-perceived communication competence in adolescents who stutter. Journal of Fluency Disorders. 2001;26:161-78. 